\title{
Postmodernismi ja vapaa sivistystyö
}

Keskustelu vapaan sivistystyön arvolähtökohdista vilkastuu. Olemme nähtävästi lähestymässä murrosta, jossa on pakko tehdä valinta tulevasta kehittämissuunnasta. Jotta vaihtoehtojen luonne selkiytyisi, pitäisi meidän ymmärtää, millaisesta murroksesta todella on kysymys. Tässä yksi vastausyritys.

On selviö, että keskustelu vapaan sivistystyön arvolähtökohdista liittyy kiinteästi siihen yleisempään keskusteluun, jota parhaillaan käydään hyvin monella tasolla koko yhteiskunnan kehittämisen suunnasta. Taustalla on se suuri yhteiskunnallinen muutosprosessi, jota yhteiskuntatieteilijät ovat kuvanneet siirtymiseksi modernista yhteiskunnasta postmoderniin. Eräs vaittelyä herättänyt kirja on ollut ranskalaisen filosofin Jean-Francois Lyotardin Tieto postmodernissa yhteiskunnassa.

Loytardin mukaan luottamus niihin metakertomuksiin, joilla tieto modernissa yhteiskunnassa on legitimoitu, on kadonnut. Hänen mukaansa modernin yhteiskunnan metakertomukset ovat olleet kahta lajia: toisessa ihmiskunta vapautuu tiedon avulla kärsimyksistään, toisessa tiedon tehtävänä on liittää kansalaiset valtioon, jota kautta avautuu tie 'Hengen elämään’.

Modernilla yhteiskunnalla on useita metakertomuksia, joissa perustellaan uskoa ihmisarvoon (humanismi), demokratian (liberalismi), tietoon (positivismi), edistykseen (valistus) ja oikeudenmukaisuuteen (sosialismi). Enää niihin ei Loytardin mukaan uskota. Tilalle on tullut tiedon pirstoutuminen, eriytyvät kielipelit, kyynisyys ja tehokkuuden maksimointi. Jos murroksen luonne on todellakin tällainen, joutuvat myös vapaan sivistystyön arvolähtökohdat koetukselle, sillä juuri vapaa sivistystyö, jos mikä, on modernin yhteiskunnan perillinen.

Vapaan sivistystyön arvolähtökohdat syntyivät ja kehittyivät modernin yhteiskunnan metakertomusten kulta-aikana ja tämä näkyy hyvin selvästi niissä. Esimerkiksi Aulis Alanen on tiivistänyt ne tutkimuksessaan sivistysjärjestöjen tehtäväkuvan muuttumisesta seuraavasti: kokonaispersoonallisuuden kehittäminen, omaehtoisuus, opinnollisuus, itsesäätelyn vapaus ja tehtäväalueen yhteiskunnallinen kasvatus ja harrastusopinnot. Aiemmin on korostettu myös tieteenomaisuutta, puolueettomuutta ja sivistyksellistä tasa-arvoa. Onko mikään muu yhteiskunnallisen toiminnan muoto tunnustanut velkaansa modernin yhteiskunnan metakertomuksille niin avoimesti kuin vapaa sivistystyö?

Mutta mihin vapaata sivistystyötä tarvitaan, jos yhteiskuntaa alkavat hallita postmodernin yhteiskunnan arvot. Emme usko tieteelliseen totuuteen, sillä mitään yhtä ja jakamatonta totuutta ei ole olemassakaan. On olemassa jokaisen oma totuus, jonka ymmärrämme omissa kielipeliemme verkostoissa omalla tavallamme. Emme pyri edistykseen, sillä toimintaamme ohjaa kyynisyys ja voitontavoittelu. Kun näemme yhteiskunnallisia ongelmia, emme pyri korjaamaan niitä oikeudenmukaisuuden nimissä. Sen sijaan toimintaamme ohjaa vahvojen ehdoista lähtevä tehokkuuden ja suorituskyvyn tavoittelu. Modernin yhteiskunnan suuri projekti hyvinvointiyhteiskunnan rakentamiseksi joutaa romukoppaan, sillä se on järjetöntä resurssien haaskausta pyrittäessä yksityisen kilpailukyvyn lisäämiseen. Esimerkiksi sivistyksellisen tasa-arvon tilalle otamme tulosvastuullisuuden ja maksupalveluperiaatteen.

Valittavanamme on kaksi vaihtoehtoa: joko lähdemme mukaan postmoderniin kehitykseen tai jatkamme modernin yhteiskunnan rakennusprojektia nykyisiin olosuhteisiin sovitettuna.

Mikäli valintamme on postmoderni vaihtoehto, voimme ottaa toimintamme perustaksi saman periaatteen, joka Valtioneuvoston päätöksellä omaksuttiin maaliskuussa 1988 ammatillisen aikuiskoulutuksen ohjenuoraksi koulutuspalveluja kysynnän mukaan niille, joilla on varaa maksaa. Joudumme tällöin luopumaan ainakin kahdesta vapaan sivistystyön kulmakivestä. Toinen on pyrkimys laajempien sivistystarpeiden herättämiseen ja tyydyttämiseen, toinen on pyrkimys sivistyksellisen tasaarvon lisäämiseen. Kun koulutuspalvelujen perustana on maksukykyinen kysyntä, on selvää, että se myös määrää koulutuksen tavoitteet ja sisällöt. Kuka olisi valmis maksamaan esim. $200 \mathrm{mk} /$ oppitunti (= kansalaisopistojen oppitunnin keskimääräinen hinta tällä hetkellä) osallistuakseen vaikkapa yhteiskunnalliseen keskustelupiiriin tai maalausryhmään? Myöskään taloudellisesti heikommassa asemassa olevista ei tarvitsisi enää kantaa huolta, sillä 
heillähän ei tunnetusti ole rahaa sivistyspalveluihin.

Jos luovumme näistä vapaan sivistystyön kulmakivistä, voimme samalla lakata puhumasta vapaasta sivistystyöstä. Se ei kuitenkaan välttämättä merkitse sitä, että vapaan sivistystyön oppilaitosten toiminta loppuisi samalla hetkellä. Päinvastoin, ei ole olemassa mitään estettä sille, etteikö esim. kansalaisopistoistakin saataisi aidossa postmodernistisessa hengessä toimivia oppilaitoksia, jotka tarjoavat virtaviivaista ajantäytettä hyvin menestyville "skimbaajille". Kysymys ei vain enää olisi vapaasta sivistystyöstä, vaan jostakin muusta. Mutta kuka osaa sanoa, mistä?

Mikäli taas haluamme jatkaa vapaan sivistystyön kehittämistä perinteisistä arvolähtökohdista, joudumme ottamaan kantaa ainakin seuraaviin kriittisiin kysymyksiin:

- suhtautuminen aikakauden keskeisiin ongelmiin ja ihmisen kykyyn ratkaista niitä

- suhtautuminen ammatilliseen koulutukseen

- suhtautuminen koulutukselliseen tasa-arvoon

- suhtautuminen vapaan sivistystyön itsemääräämisoikeuteen.

Ensimmäinen kysymys on tärkeä sen vuoksi, että jos emme enää luota ihmisen kykyyn ratkaista aikakauden keskeisiä ongelmia, ei vapaalle sivistystyöllekään jää todellista sivistystehtävää. Samalla kun ihminen tuomitaan mahdollisuutensa menettäneeksi, samalla loppuu mielekkyys kaikilta sivistämispyrkimyksiltä. Voimme lopullisesti antautua eskapismiin ja jäädä odottelemaan viimeistä romahdusta.

Myöskin toinen kysymys on yhä tärkeä vapaan sivistystyön kannalta, vaikka jako ammatillisen ja yleissivistävän koulutuksen välillä ei enää pädekään samalla tavalla kuin aikaisemmin. Yhä useammat perinteiseen yleissivistykseen kuuluvat asiat tulevat välttämättömiksi ammatissa toimimiselle, ja päinvastoin. Silti on olemassa koulutusta, jota voi huoleti kutsua ammatilliseksi koulutukseksi, ja joka poikkeaa perusluonteeltaan siitä koulutuksesta, jota kutsutaan vapaaksi sivistystyöksi.

Varsinainen ammatillinen koulutus ei koskaan voi olla siinä mielessä 'vapaata' kuin vapaa sivistystyö, sillä ammatillisen koulutuksen tavoitteet ja sisällöt ovat 'sidottuja' työvoiman ammattitaitovaatimuksiin. Mitä enemmän sivistystyön oppilaitoksissa annetaan työvoiman ammattitaitovaatimuksiin sidottua koulutusta, sitä pienemmäksi käy vapaan sivistystyön todellinen vapaus. Ammattitaitovaatimukset määritellään aina jossakin muualla kuin vapaan sivistystyön oppilaitoksessa. Järjestäessään ammatillista koulutusta vapaalle sivistys- työlle jää käytännössä ainoastaan vapaus ottaa tai jättää jossakin muualla suunniteltu koulutus. Meidän on siis kysyttävä jatkuvasti millä edellytyksillä ja missä määrin vapaan sivistystyön oppilaitoksissa voidaan antaa ammatillista koulutusta, jos emme tahdo ehdoitta luopua vapaan sivistystyön perusolemuksesta.

Suhtautuminen ammatilliseen aikuiskoulutukseen on tullut entistäkin ajankohtaisemmaksi Valtioneuvoston maaliskuisen periaatepäätöksen jälkeen. Sehän merkitsee todella ratkaisevaa resurssilisää ammatilliseen aikuiskoulutukseen, mikäli päätös myös käytännössä toteutetaan. Päätös osoittaa, että ammatillisen aikuiskoulutuksen tarpeet pyritään ensisijaisesti hoitamaan tämän sektorin omien koulutusorganisaatioiden kautta lisäämällä niiden lukumäärää ja parantamalla niiden toimintaedellytyksiä. Samalla ammatillista aikuiskoulutusta antavat organisaatiot pannaan entistä selkeämmin kilpailemaan paikasta auringossa. Tätä taustaa vasten vapaan sivistystyön oppilaitosten kannattaa varmasti miettiä vähintään kaksi kertaa, mihin ne suuntaavat omat kehittämismyrkimyksensä. Viime aikoinahan on ollut selvästi nähtävissä, että myös vapaan sivistystyön oppilaitokset ovat alkaneet hokea yhä useammin tämän hetken taikasanaa: ammatillista täydennyskoulutusta.

Valtioneuvoston periaatepäätös on aktualisoinut uudelleen myös kysymyksen koulutuksellisesta tasa-arvosta. Kun ammatillisen aikuiskoulutuksen toimintaperiaatteeksi ollaan nyt omaksumassa tarjonnan suuntaamista maksukykyisen kysynnän mukaan, joutuu koulutuksellisen tasa-arvon vaatimus yhä kauemmaksi taka-alalle. Muutos Aikuiskoulutuskomitean linjauksista on huimaava, eikä aikaa ole kulunut kuin 15 vuotta. Pitäisikö vapaan sivistystyönkin mukautua tällaiseen vahvojen ehdoista lähtevään toimintamalliin?

Kysymys vapaan sivistystyön itsemääräämisoikeudesta on tullut edellä esille suhtautumisessa ammatilliseen aikuiskoulutukseen, mutta siihen liittyy eräs toinenkin näkökohta, joka kaipaa kommentointia. Jos aikuiskoulutuksen kehittämisessä tavoitellaan jatkuvaa tehokkuuden lisäämistä, tullaan varmasti ennen pitkää sellaisenkin kysymyksen äärelle, että onko Suomella varaa ylläpitää sellaista järjestelmää kuin vapaa sivistystyö. Vaikka vapaan sivistystyön organisaatioita ja työmuotoja kehitettäisiin kuinka pitkälle tahansa, on siinä kuitenkin aina viime kädessä kysymys ihmisten omaehtoisten sivistyspyrkimysten tukemisesta. Niitä ei läheskään aina pysty perustelemaan tarpeellisiksi, jos toiminnan tarpeellisuutta mitataan ainoastaan tehokkuuden kriteereillä. Kysymys on siitä, millaisen metakertomukseen ihmisyydestä ja sivistyksestä me uskomme: moderniin vai postmoderniin. 